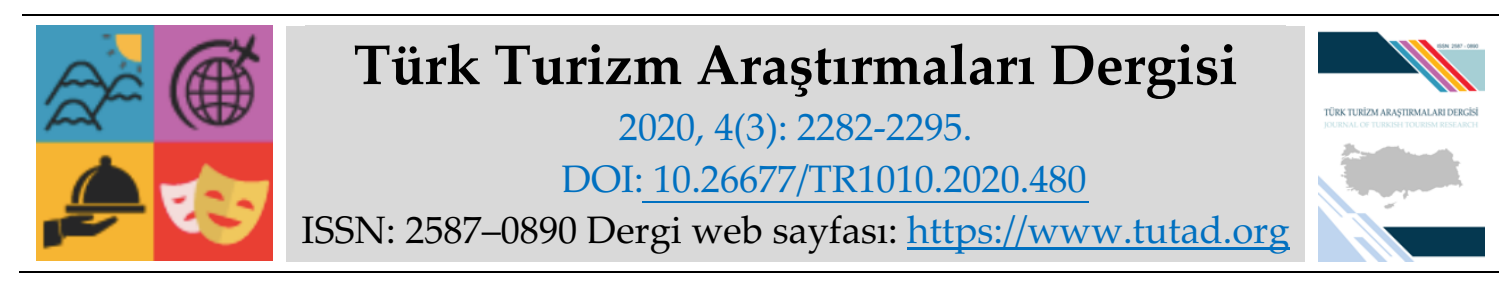

ARASTTIRMA MAKALESI

\title{
Turizm Öğrencilerinin Yamaç Paraşütü Algısı: Kelime İlişkilendirme Testi Uygulamasi
}

Arş. Gör. Dr. Funda ÖN ESEN, Muğla Sıtkı Koçman Üniversitesi, Turizm Fakültesi, Muğla, eposta: fundaesen@mu.edu.tr

ORCID: https://orcid.org/0000-0003-2428-7803

Doç. Dr. Burhan KILIÇ, Muğla Sıtkı Koçman Üniversitesi, Turizm Fakültesi, Muğla, e-posta: bkilic@mu.edu.tr

ORCID: https://orcid.org/0000-0002-1136-5107

\section{Öz}

Araştırmanın amacı Muğla Sıtkı Koçman Üniversitesi Turizm Fakültesi'nde öğrenim gören lisans öğrencilerinin yamaç paraşütü kavramına ilişkin bilişsel yapılarını Kelime İlişkilendirme Testi (KIT) ile ortaya koymaktır. Amaç doğrultusunda fakültede öğrenim gören 3. ve 4. sinıf öğrencileri araştırmanın örneklemini oluşturmaktadır. Araştırma, betimsel tarama modelinde olup, veri toplama aracı olarak Kelime İlişkilendirme Testi kullanılmışır. Araştırma sonucunda, duygu ve düşünceler, yapma nedenleri, doğal güzellik, olumsuzluk, yer/mekan, ekipman ve şartlar, maliyet, sektör, kişilik özellikleri, sosyal medya ve diğer olarak adlandırılan kategoriler ortaya çıkmıştır. Katılımcıların en çok tekrarladığı kelimeler heyecan, korku ve adrenalin gibi duygu ve düşüncelere yöneliktir. Bunun yanı sıra, öğrencilerin kurmuş oldukları cümlelerde yamaç paraşütü kavramına ilişkin bilgi sahibi oldukları tespit edilmiştir.

Anahtar Kelimeler: Yamaç Paraşütü, Kelime İlişkilendirme Testi, Turizm Öğrencileri.

Makale Gönderme Tarihi: 02.04.2020

Makale Kabul Tarihi: 03.07.2020

\section{Önerilen Atıf:}

Ön Esen, F. ve Kılıç, B. (2020). Turizm Öğrencilerinin Yamaç Paraşütü Algısı: Kelime İlişkilendirme Testi Uygulaması, Türk Turizm Araştırmaları Dergisi, 4(3): 2282-2295.

(c) 2020 Türk Turizm Araştırmaları Dergisi. 


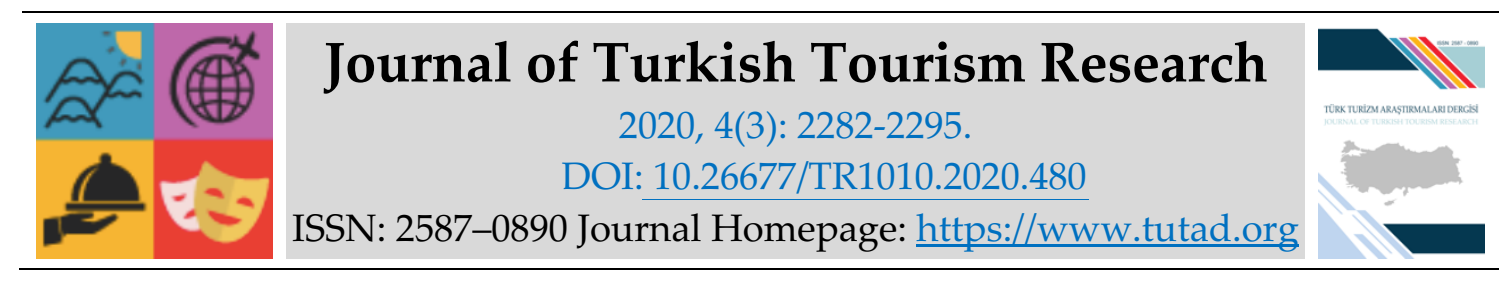

\title{
$\underline{\text { RESEARCH PAPER }}$
}

\section{Paragliding Perception of Tourism Students: Application of The Word Association Test}

Dr. Funda ÖN ESEN, Muğla Sıtkı Koçman University, Faculty of Tourism, Muğla, e-mail: fundaesen@mu.edu.tr

ORCID: https://orcid.org/0000-0003-2428-7803

Associate Prof. Dr. Burhan KILIÇ, Muğla Sıtkı Koçman University, Faculty of Tourism, Muğla, email: bkilic@mu.edu.tr

ORCID: https://orcid.org/0000-0002-1136-5107

\begin{abstract}
The aim of the research is to reveal the cognitive structures of students about the concept of paragliding with the Word Association Test in Muğla Sttkı Koçman University Tourism Faculty. In line with the purpose, juniors and seniors studying at the faculty constitute the sample of the research. The research is in descriptive survey model and Word Association Test was used as data collection tool. As a result of the research, the categories named as emotions and thoughts, reasons for doing, natural beauty, negativity, place, equipment and conditions, cost, sector, personality characteristics, social media and other emerged. The words that the participants repeat most are directed to emotions and thoughts such as excitement, fear and adrenaline. In addition, students made a sentence related to the concept of paragliding. Accordingly, it was determined that they have knowledge about the concept of paragliding.
\end{abstract}

Keywords: Paragliding, Word Association Test, Tourism Students.

Received: 02.04.2020

Accepted: 03.07.2020

\section{Suggested Citation:}

Ön Esen, F. and Kılıç, B. (2020). Paragliding Perception of Tourism Students and: Application of The Word Association Test, Journal of Turkish Tourism Research, 4(3): 2282-2295.

(c) 2020 Türk Turizm Araştırmaları Dergisi. 


\section{Gíriş}

"Yapabildiŏimiz her şeyi yapsaydık, buna kendimiz bile şaşardık."

Thomas Edison

Tarih boyunca kuşlar gibi özgürce uçabilmek; insanoğlunun içinde yaşattığı en büyük düşlerden birisi olmuştur. Bu gaye uğruna, bazı dâhiler ölümü bile göze alıp uçma denemeleri yapmışlardır. İnsanoğlunun kuşları gözlemlemeye başladığı ilk günlerden beri var olan uçma tutkusunun en erken öyküsü, Yunan Mitolojisindeki anlatımıyla Daedalus ve oğlu İkarus'un efsanesidir (Kılıç, 2015). Efsaneye göre; "Kral Minos, ustasını ve oğlunu labirente mahkûm etmiştir. Daidalus, oğlu İkarus ile birlikte labirentte bir süre mahkûm olarak kahır. Yine bir süre sonra, aklına bal mumu ve tüylerden, tıpk kuşlarda olduğu gibi kendilerine kanat yapma fikri gelir. Çünkü labirentten uçmak dışında başka türlü kaçamayacaklardır. Aklına gelen bu fikri uygulamaya koyan Daidalus ahşap bir sistem üzerine kuş tüylerini yerleştirir ve onları bal mumu ile destekler. İki çift kanat en sonunda hazır olur. Birini oğluna diğerini ise kendisine takan Daidalus artık kaçmak için hazırdır. Daidalus uçmadan önce oğluna, çok alçaktan uçarsa denize düşeceğini, çok yüksekten uçarsa güneş ışınları yüzünden kanatlarını kaybedeceğini söyler. İkarus'u dengeli bir şekilde uçması gerektiği konusunda sıkı sıkı tembihledikten sonra ikisi de uçmaya başlarlar" (www.tarihlisanat.com). İşte böylece bilinen en eski efsanevi insanlı uçuşu gerçekleştirmiş olurlar. İnsanların kuşları taklit etmekten öteye gidemedikleri bu dönem ilkel havacılık olarak adlandırılmaktadır. Ancak ilerleyen dönemlerde balon, zeplin, planör gibi değişik tipte hava taşıtları ortaya çıkmış (Kılıç, 2015) ve günümüzde gelişerek daha iyi hale gelmişlerdir. Bu gelişmelerle birlikte hava sporları da ilgi çekmeye başlamıştır.

Heyecan ve macera arayışı içinde dünyayı keşfetmek, insan için yeni bir olay değildir. Bu ihtiyaç, insan doğasının bir parçasıdır ve dünyadaki çeşitli macera aktivitelerinin popülerliğinde büyük bir rol oynamaktadır (Hsieh, 2007). Artan kentleşme ile birlikte insanlar, mekânlardan uzaklaşmayı isteyerek doğaya açılmayı yeni bir etkinlik biçimi olarak benimsemektedir. Bu istek içinde rutinden kaçış, gürültüden ve kentsel kirlilikten uzaklaşma vb. gibi birçok nedenin yanında, yeni heyecan ve adrenalin arayışları da dikkat çekmektedir. Bu doğrultuda, doğada yapılan sportif etkinlikler gittikçe artan bir arz ve talep yaratmaktadır (Koçak ve Balcı, 2010). Türkiye'nin arz kaynakları incelendiğinde; bu sportif faaliyetlerinden biri de gün geçtikçe gelişen ve genellikle stres atma, adrenalin arayışı olarak tercih edilen bir doğa ve hava sporu olan yamaç paraşütüdür.

Yamaç paraşütü, gün geçtikçe daha fazla kişi tarafından deneyimlenmektedir. Her geçen gün yeni paraşüt alanlarının açılması ve var olan alanların geliştirilmesi bu hava sporunun destinasyonlar için öneminin arttığını göstermektedir (Saçlı ve Kahraman, 2019). Bu doğrultuda çalışmanın konusu yamaç paraşütü olarak belirlenmiştir. Yamaç paraşütü ile ilgili yapılmış çalışmalar (Gauler ve Sauter, 2006; Chang ve Huang, 2012; Arslan Ayazlar, 2015; Karademir ve Güven, 2016; Özçiriş, 2017; Barut vd., 2019; Saçlı ve Kahraman, 2019) incelendiğinde, pilotların, yerel yönetimin ya da paraşüt deneyimini yaşayanların dâhil olduğu; yamaç paraşütü ile ilgili sorunların, kazaların, akı deneyiminin, stres ve kaygı düzeyinin, motivasyon ve memnuniyet konularının işlendiği görülmektedir. Ancak yamaç paraşütüne ilişkin algıların belirlenmesine yönelik bir çalışmaya rastlanmamıştır. Bu bağlamda sektörde istihdam sağlamayı düşünen turizm öğrencilerinin yamaç paraşütü kavramına ilişkin düşünceleri merak konusu olmuş ve araştırmanın amacı Muğla Sıtkı Koçman Üniversitesi Turizm Fakültesi'nde öğrenim gören lisans öğrencilerinin yamaç paraşütü kavramına ilişkin bilişsel yapılarını Kelime İlişkilendirme Testi (KİT) ile ortaya koymak olarak belirlenmiştir. 


\section{LIITERATÜR}

\section{Yamaç Paraşütü}

Yamaç paraşütü, herhangi bir motor gücü olmaksızın, sadece yükselen hava akımları ile süzülerek uçabilen, özenli ve karmaşık tasarımların sonucunda oluşan hafif, basit bir hava aracıdır. Yamaç Paraşütü ile küçük tepelerden kalkış yaparak yerden yüzlerce metre yüksekliklere çıkılabilmekte ve gökyüzünde saatlerce kalıp kilometrelerce uzaklara uçulabilmektedir. Bu bağlamda yamaç paraşütü sporunun doğmasıyla birlikte yüz binlerce insan, doğada kuşlar gibi süzülmenin ve yeryüzüne kuşbakışı bakmanın keyfini çok kolay bir şekilde yaşamaktadır. Yamaç paraşütünün doğayla iç içe olması sebebiyle yamaç paraşütü, dünyada büyük bir hızla gelişmekte ve tercih edilmektedir (Türk Hava Kurumu, 2009; Pirselimoğlu Batman ve Demirel, 2015; Özçiriş, 2017).

Yamaç paraşütü sporunun ilk uygulamaları 1980'li yıllarda Fransız dağcıların uçaktan atlanan paraşütlerle (skydive paraşütleriyle) yamaçlardan koşarak kalkış denemeleriyle başlayan bir etkinliktir (Özçiriş, 2017). Türkiye'de ise yamaçtan koşarak uçuş denemeleri ilk olarak 1985'te Türk Hava Kurumu (THK) paraşütçüleri tarafından dünyada olduğu gibi serbest atlayış paraşütleriyle Erzincan'ın Çakırman Köyü'nde yapılmıştır. Daha sonra bunu AdıyamanNemrut, Kayseri-Ali Dağı ve Ankara-Kızılcahamam'da yapılan uçuşlar izlemiştir (Karademir ve Güven, 2016). Ancak Türkiye'de yamaç paraşütü sporu, 1990 başlarında Fethiye Ölüdeniz bölgesinde Baba Dağı'nın yabancı pilotlar tarafından keşfedilmesi ile tanınmış, ilk olarak üniversite kulüplerinde aktif olarak başlamış (Akça, 2016) ve Türkiye' de oldukça hızlı bir gelişim göstermiştir. Türkiye, yamaç paraşütü sporu için oldukça elverişli destinasyonlara sahiptir. Türkiye'nin coğrafi fiziksel yapısı dağlık bölgede bulunmuş olması ve her tarafının tepeler ve yüksek engebeli yapısı ile kaplı olmasından ötürü hemen her şehirde uçuşa uygun yerler bulunabilmektedir. Özellikle Türkiye'nin bilinen uçuş noktaları arasında Babadağ-Fethiye ilk sırada yer almaktadır (Saçlı ve Kahraman, 2019; Akoğlan Kozak ve Bahçe, 2009). Fethiye'nin yanı sıra Denizli-Pamukkale, Ankara-Gölbaşı, Bolu-Abant, Eğirdir, Kayseri, Eskişehir-İnönü diğer başlıca uçuş noktalarıdır (Pirselimoğlu Batman ve Demirel, 2015).

\section{Yamaç Paraşütü Motivasyonları}

Yamaç paraşütü, dünya genelinde spor turizmi kapsamında hava sporları dalında geçmesinin yanında, son yıllarda gelişme gösteren macera turizmi kapsamında da değerlendirilmektedir. Bu doğrultuda yamaç paraşütü hem doğa sporu hem de macera etkinliği ya da sporudur. Kısacası yamaç paraşütü, doğada yapılan bir macera sporu olarak tanımlanabilir. Bu bağlamda Swarbrooke ve Horner (2007)'a göre; turistleri belirli bir ürün veya hizmeti satın almaya iten nedenler (Akyurt Kurnaz ve Kılıç, 2020: 10) olarak tanımlanan motivasyonları, yamaç paraşütü etkinliği için hem doğa hem de macera olarak iki farklı şekilde açıklamak gerekmektedir.

Doğaya açılmayı yeni bir etkinlik haline getiren insanlar, rutinden kaçış, gürültüden ve kentsel kirlilikten uzaklaşma gibi birçok nedenin yanı sıra, yeni heyecan ve gerilim arayışları içerisinde oldukları için doğada yapılan sportif etkinliklere katılmaktadır (Koçak ve Balcı, 2010). Doğaseverler; doğayla bütünleşmek, sağlık, ilgi alanlarının olması, sıkıntıdan ve monotonluktan kurtulmak, stres atmak, rahatlamak gibi nedenlerle doğa sporu yapmakta ve kendilerini daha mutlu, sağlıklı, güçlü ve rahatlamış hissetmektedirler. Bunun yanı sıra doğa sporu yaparken yeni kişilerle tanışmakta ve yeni şeyler öğrenmektedirler (Ardahan ve Yerlisu Lapa, 2011). 
Macera sporları, zaman akışı, mevcut işleri düzenleme, kendini ifade etme ve değişim ihtiyacı, doğayı keşfetme, fiziksel aktivite, düşünme, kendi sınırlarını aşma, boş zaman faaliyeti, güçlü duyguları deneyimleme yeteneği, eğlence, özgürlük, sağlık ve yaşam kalitesi gibi bir dizi sosyal faktörlerin sonucudur (Paixaol ve Tucher, 2012: 6). Macera turizmi kapsamında yapilan etkinliklerin merkezinde risk vardır. Ancak bu faaliyetlerde riskten ziyade insanlar korku ve heyecan aramaktadır (Cater, 2006). Paixaol ve Tucher (2012) de, yamaç paraşütünde özgürlük hissi ve korku duygularının riskten daha önemli olduğunu belirtmiştir. Bunların yanı sıra macera turizmi sevenler, stresten kurtulma, kaçış, rahatlama, değişiklik, yenilik (Naidood vd., 2015), yeni yerleri keşfetme merakı ve yaşamın yoğunluğundan uzaklaşma (Koday vd., 2018) amacıyla etkinliklere katılmaktadır. Ayrıca adrenalin, risk, heyecan ve macera arayanlar, macera turizmini tercih etmektedir (Sarıbaş ve Öter, 2013).

Yamaç paraşütü etkinliği özelinde yapılmış çalışmalarda ise; macera severler özgürlük, heyecan, gökyüzünden bakmak, macera, risk alma, yükseklik korkusunu yenme, huzur bulma ve farklılaşma isteği gibi nedenlerden dolayı yamaç paraşütü etkinliğine katıldıklarını (Saçlı ve Kahraman, 2019); havada olmak, uçabilmek ve özgürlük hissi gibi duygular hissettiklerini (Arslan Ayazlar, 2015) belirtmişlerdir. Bunlara ek olarak Paixaol ve Tucher (2012), yamaç paraşütü yapan bireylerin güvenli ve başarılı bir uçuşun korku, heyecan ve baş dönmesi kadar önemli olduğunun farkında olmaları gerektiğini vurgulamıştır. Barut vd. (2019) ise, düzenli olarak doğa yürüyüşü ve yamaç paraşütü etkinliklerine katılan bireylerin yaşam doyumlarının ve özyeterliklerinin yüksek olduğunu ve bu etkinliklere katılarak kendilerini olumlu hislere sürükleyecek enerjiyi kendilerine sağladıklarını ifade etmiştir.

Gerek macera etkinlikleri gerekse doğa sporu çalışmalarından yola çıkarak; bireylerin öncelikle heyecan, adrenalin, korku ve özgürlük, daha sonra ise yenilik, farklı olmak, stresten kurtulma, kaçış, doğayla iç içe olmak, gökyüzünden manzarayı seyretmek, havada olmak, risk almak gibi nedenlerle yamaç paraşütü etkinliğini yapmayı tercih ettikleri söylenilebilir. Bunların yanı sıra enerji atmak, psikolojik olarak rahatlamak, mutluluk ve yaşam doyumu da yamaç paraşütü motivasyonları arasında yer almaktadır. Bu bağlamda, tehlikeli ve riskli bir etkinlik olan yamaç paraşütünü denemek isteyen bireylerin, bu etkinliği yapma motivasyonlarının farklılık gösterdiğini de belirtmek gerekir.

\section{YÖNTEM}

Araştırma, betimsel tarama modelinde olup, veri toplama aracı olarak Kelime İlişkilendirme Testi (KİT) kullanılmıştır. Timur ve Taşar (2011: 131), Kelime İlişkilendirme Testinin bilişsel yapıları araştırmak için kullanılan en yaygın ve en eski metotlardan biri olduğunu belirtmiştir. Kelime İlişkilendirme Testi, öğrencinin bilişsel yapısını ve uzun dönemli hafızadan gelen kelimeler ile anahtar kavram arası ilişkilerin anlamlı olup olmadığına dair yanıt almamıza yarayan alternatif ölçme değerlendirme tekniklerinden birisidir (Bahar vd., 1999). Kelime İlişkilendirme Testi, anahtar kavrama (uyarıcı kelime) verilen cevap kelimelerine bağlı olarak kişilerin bilişsel yapısındaki kavram ve kavramlar arası bağları araştırmak, varsayılan bir düşünceyi ortaya çıkarmak ve belirli bir uyarıcı ile karşılaştığında zihnin yönünü ortaya koyan bir gösterge elde etmek için tasarlanmıştır (Doğan vd., 2018). Kelime İlişkilendirme Testi, çoğunlukla fen ve eğitim bilimlerinde kullanılmakta olup, son yıllarda turizm alanında da KİT uygulanarak yapılan çalışmalar (Keskin ve Örgün, 2015; Keskin vd., 2017; Yücel Güngör vd., 2017; Doğan vd., 2018; Akyurt, 2019; Onat ve Keskin, 2019; Bucak ve Yiğit, 2020) mevcuttur.

Araştırmanın amacına yönelik fakültede Seyahat İşletmeciliği, Konaklama İşletmeciliği ve Yiyecek-İçecek İşletmeciliği programlarında öğrenim gören 3. ve 4. Sınıf öğrencileri araştırmanın 
örneklemini oluşturmaktadır. Örneklem olarak söz konusu fakültenin 3. ve 4. Sınıf öğrencilerin belirlenmesinin nedeni, zaman ve maddi kaynakların kısıtlllığ ile birlikte, turizm sektöründe çalışmış olmaları (sektörsel tecrübe) ve eğitimlerinin \%50'sini tamamlamış (bilgi birikimi) olmalarıdır. Öğrencilere yamaç paraşütü kavramı verilmiş ve belirli bir süre içinde kavramın akıllarına getirdiği 10 adet kelime yazmaları istenmiştir. Her bir kavram için, öğrencilerin 30 saniye içinde o kelime ile yakından ilişkili olduğunu düşündükleri kelimeleri yazmaları beklenmektedir (Bahar vd., 1999). Kelimelerin alt alta yazılmalarının nedeni ise, öğrencilerin her defasında verilen kavramı düşünerek ilişkilendirecekleri kelimeleri yazmalarının sağlanmasıdır. Çünkü anahtar kavrama tekrar dönmezse, en son ilişkilendirmiş olduğu kavramın aklına getirdiği kelimeleri yazması muhtemeldir. Bu da testin amacını zedelemektedir (Bahar ve Özatlı, 2003). Çalışmada bu kelimelere ek olarak, kelimelerin sonunda yamaç paraşütü ile ilgili akıllarına gelen bir cümle kurmaları istenmiştir. Nartgün (2006), anahtar kavram ile ilgili yazılan kelimelerin sadece hatırlatma düzeyinde olduğunu, anahtar kavramla anlamlı bir ilişkisi olmayan bir çağrışım ürünü olabileceğini belirtmiştir. Bu nedenle öğrencilerin verilen anahtar kelime ile ilgili cümle yazmaları çalışma açısından önem teşkil etmektedir. Nitekim Ercan vd., (2010: 140)'a göre, ilgili cümle; tek bir cevap kelimeye göre daha kompleks ve üst düzey yapıda olacağından cümlenin bilimsel olup olmaması, farklı nitelikte kavram yanılgıları içerip içermediği gibi durumlar değerlendirme sürecini etkilemektedir. Aşağıda örnek bir sayfa düzeni verilmiştir:

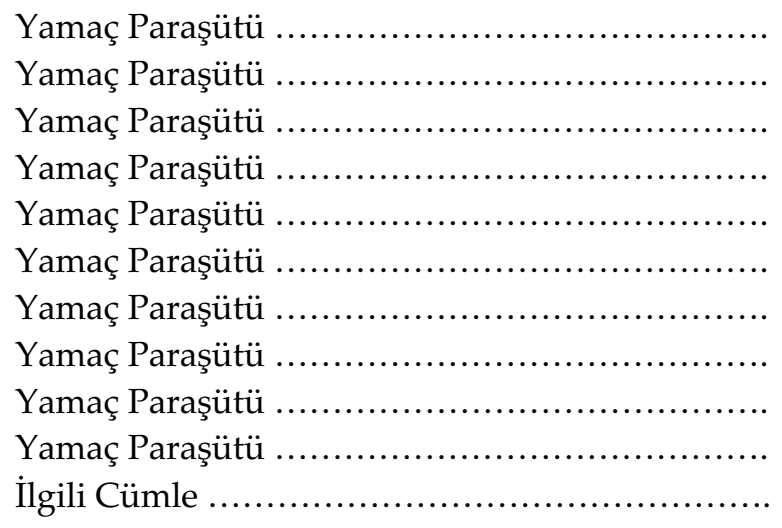

Uygulamada teste katılan öğrencilerle yüz yüze görüşülmüştür. Öncelikle KİT hakkında bilgi verilmiş ve farklı kavramlara yönelik örneklerle açıklanmıştır. Araştırma yoğun katılımın olduğu zorunlu derslerde yapılmıştır. Toplam 239 kişiye ulaşılmıştır. Analiz aşamasında öncelikle öğrencilerin cevap kâğıtları 1'den 239'a kadar numaralandırılmış, anahtar kavrama ilişkin verilen cevap kelimeler ayrıntılı bir şekilde incelenmiş ve daha sonra toplanan veriler betimsel analiz ile çözümlenmiştir. Verilen kavrama yanıt olarak yazılan kelimelerin sayısı ve çeşidi değerlendirmeye tabi tutulmuştur. KİT sonucunda üretilen cevap kelimelerin sayısı, verilerin analizinde kullanılan metotlardan birisi olup, bir kavramla ilişkilendirilen kelimelerin sayısı ve niteliği o kavramın anlaşılıp anlaşılmadığını belirlemekte kullanılabilmektedir. Çünkü bir kavramın iyi anlaşılması kavramla ilişkilendirilen diğer kelimelere bağlıdır (Taşdere vd., 2014: 134). Öğrencilerden elde edilen kelimeler anlamsal ilişkilerine göre kategorize edilmiş, kelimelerin sıklığı hesaplanarak frekans tablosu ve en fazla tekrar edilen kelimeler analiz edilerek kavram haritası oluşturulmuştur. Kavram haritası, öğrencilerin bilişsel yapısındaki kavramlar arasındaki bağları ve geçişleri gözler önüne seren, diğer bir ifade ile görsel hafızaya hitap eden bir öğretim tekniğidir (Bahar, 2001: 25). 


\section{BULGULAR}

Araştırmaya katılan öğrencilerin 121'i kadın, 118'i erkek; 84'ü Yiyecek-İçecek İşletmeciliği, 82'si Konaklama İşletmeciliği ve 73'ü Seyahat İşletmeciliği bölümünde; $195^{\prime}$ i 4.sınıfta ve 44'ü 3.sınıfta öğrenim görmektedir. Katılımcılardan elde edilen veriler sonucunda, yamaç paraşütü kavramına ilişkin verilen yanıtlardan 11 kategori ortaya çıkmış ve Tablo 1'de listelenmiştir. Tablo 1 incelendiğinde, anahtar kavrama ilişkin toplam 132 farklı kelime ortaya çıkığı ve bu kelimelerin 2296 defa tekrarlandığı görülmektedir. Veri analizinin sonucunda yamaç paraşütü ile ilgili en baskın kategori duygu ve düşünceler olarak belirlenmiştir. Bunu sırasıyla, yapma nedenleri, doğal güzellik, olumsuzluk, yer/mekan, ekipman ve şartlar, maliyet, sektör, kişilik özellikleri, sosyal medya ve diğer olarak adlandırılan kategoriler takip etmektedir.

Tablo 1: Anahtar Kavrama İlişkin Kategoriler ve Kelimeler

\begin{tabular}{|c|c|c|c|c|}
\hline KATEGORİLER & \multicolumn{2}{|c|}{ KELIMELER VE FREKANSLARI } & $\begin{array}{l}\text { TOPLAM } \\
\text { FREKANS }\end{array}$ & YÜZDE \\
\hline \multirow{12}{*}{$\begin{array}{c}\text { DUYGU } \\
\text { VE } \\
\text { DÜŞÜNCELER }\end{array}$} & Heyecan (166) & Huzur (10) & \multirow{12}{*}{839} & \multirow{12}{*}{36,6} \\
\hline & Korku (144) & Nefes (8) & & \\
\hline & Adrenalin (142) & Endişe (5) & & \\
\hline & Özgürlük (56) & İlgi çekici (4) & & \\
\hline & Aksiyon (55) & Enerji (3) & & \\
\hline & Eğlence (52) & Sonsuzluk (3) & & \\
\hline & Tehlike (48) & Olağanüstü (3) & & \\
\hline & Macera (44) & Tarifsiz (1) & & \\
\hline & Mutluluk (35) & İnanılmaz (1) & & \\
\hline & Tutku (14) & Hayata tutunma (1) & & \\
\hline & Stres (13) & Ağlama (1) & & \\
\hline & Çılgınlık (13) & Boşluk (1) & & \\
\hline & Uçmak (84) & Kendini gerçekleştirme (4) & & \\
\hline & Spor (53) & Rahatlama/düşünmeme (4) & & \\
\hline & Zevk (34) & Kaçış (3) & & \\
\hline & Deneyim (32) & Gösteriş/hava atmak (2) & & \\
\hline & Aktivite (17) & Havada olmak (2) & & \\
\hline & Atlamak (15) & Bağırmak (2) & & \\
\hline & Süzülmek (13) & Sosyalleşme (1) & & \\
\hline YAPMA & Hobi (13) & Serbest atlayış (1) & 349 & 15,2 \\
\hline NEDENLERI & Değişiklik (12) & Tirmanmak (1) & & \\
\hline & Hatıra (10) & Popülerlik (1) & & \\
\hline & Hız Tutkusu (10) & İzlemek (1) & & \\
\hline & Hayal (8) & Ziplamak (1) & & \\
\hline & Hayat/yaşam (7) & Gezmek (1) & & \\
\hline & Akrobasi (5) & Hafiflemek (1) & & \\
\hline & Merak (5) & Mezuniyet hediyesi (1) & & \\
\hline & Hissetmek (5) & & & \\
\hline & Manzara (89) & Yamaç (12) & & \\
\hline & Dağ (79) & Kuşbakışı (11) & & \\
\hline & Gökyüzü (44) & Zirve (7) & & \\
\hline CÜZFU İK & Deniz (31) & Güneş (6) & 325 & 14,2 \\
\hline & Mavi (14) & Renkli (3) & & \\
\hline & Bulut (14) & Yeryüzü (1) & & \\
\hline & Orman (13) & Atmosfer (1) & & \\
\hline
\end{tabular}




\begin{tabular}{|c|c|c|c|c|}
\hline \multirow{9}{*}{ OLUMSUZLUK } & Yükseklik (99) & Kalp atışı (6) & \multirow{9}{*}{271} & \multirow{9}{*}{11,8} \\
\hline & Ölüm (42) & Mide bulantısı (3) & & \\
\hline & Risk (28) & Panik (3) & & \\
\hline & Gerilim (24) & Tepe/kayalık (2) & & \\
\hline & Yükseklik korkusu (16) & Kalp krizi (2) & & \\
\hline & Uçurum (16) & Bayılmak (1) & & \\
\hline & Düşmek (13) & Dağa çarpmak (1) & & \\
\hline & Kaza (7) & Güvensiz (1) & & \\
\hline & Güvenlik (7) & & & \\
\hline \multirow{2}{*}{ YER / MEKÂN } & Fethiye (110) & Ölüdeniz (18) & \multirow{2}{*}{157} & \multirow{2}{*}{6,8} \\
\hline & Babadağ (27) & Eskişehir (2) & & \\
\hline \multirow{10}{*}{$\begin{array}{l}\text { EKIPMAN } \\
\text { VE } \\
\text { ŞARTLAR }\end{array}$} & Rüzgâr (44) & Sırt çantası (2) & \multirow{10}{*}{133} & \multirow{10}{*}{5,8} \\
\hline & Hava (24) & Zorluk (2) & & \\
\hline & Paraşüt (19) & Firtına (1) & & \\
\hline & Eğitmen (13) & Basınç (1) & & \\
\hline & İp (7) & Aksiyon kamerası (1) & & \\
\hline & Eğitim (6) & Gözlük (1) & & \\
\hline & Uçurtma (3) & Kiyafet (1) & & \\
\hline & $\operatorname{Kamp}(2)$ & Telsiz (1) & & \\
\hline & Balon (2) & Pist (1) & & \\
\hline & Kask (2) & & & \\
\hline MALIYET & Para (46) & Pahalı (41) & 87 & 3,8 \\
\hline \multirow{3}{*}{ SEKTÖR } & Turizm (17) & Yaz (6) & \multirow{3}{*}{49} & \multirow{3}{*}{2,1} \\
\hline & Tatil (15) & Ticaret / Gelir (5) & & \\
\hline & Turist (6) & & & \\
\hline $\begin{array}{c}\text { KİSSİLIKK } \\
\text { ÖZELLİKLERİ }\end{array}$ & Cesaret (38) & Özgüven (5) & 43 & 1,9 \\
\hline \multirow{2}{*}{$\begin{array}{l}\text { SOSYAL } \\
\text { MEDYA }\end{array}$} & Fotoğraf/Selfi (20) & Instagram (2) & \multirow{2}{*}{27} & \multirow{2}{*}{1,2} \\
\hline & Kamera/video (5) & & & \\
\hline \multirow{3}{*}{ DİĞER } & Kanat (5) & Sportif havacılık (2) & \multirow{3}{*}{16} & \multirow{3}{*}{0,6} \\
\hline & Sivil havacılık (4) & Hava kuvvetleri (1) & & \\
\hline & Uçaktan atlama (4) & & & \\
\hline TOPLAM & & 132 & 2296 & 100 \\
\hline
\end{tabular}

'Duygular ve Düşünceler' kategorisinde, öğrenciler heyecan, korku ve adrenalin üzerine; 'Yapma Nedenleri' kategorisinde uçmak, spor, zevk ve deneyim üzerine; 'Doğal Güzellikler' kategorisinde manzara, dağ, gökyüzü ve deniz üzerine; 'Olumsuzluk' kategorisinde yükseklik, ölüm, risk ve gerilim üzerine; 'Yer/Mekan' kategorisinde Fethiye üzerine; 'Ekipman ve Şartlar' kategorisinde rüzgar, hava, paraşüt ve eğitmen üzerine; 'Maliyet' kategorisinde para üzerine; 'Sektör' kategorisinde turizm ve tatil üzerine; 'Kişilik Özellikleri' kategorisinde cesaret üzerine ve 'Sosyal Medya' kategorisinde fotoğraf/selfi üzerine yoğunlaşmışlardır. Çalışmada bu kategoriler ve kategorilerde yer alan kelimelere dayanarak kavram haritası oluşturulmuş ve Şekil 1 'de verilmiştir. Kavram haritasında 20'nin altında frekansı olan kelimelere yer verilmemiştir. Dolayısıyla 8. kategori olan 'Sektör' ve 11. kategori olan 'Diğer' kavram haritasında bulunmamaktadir. 


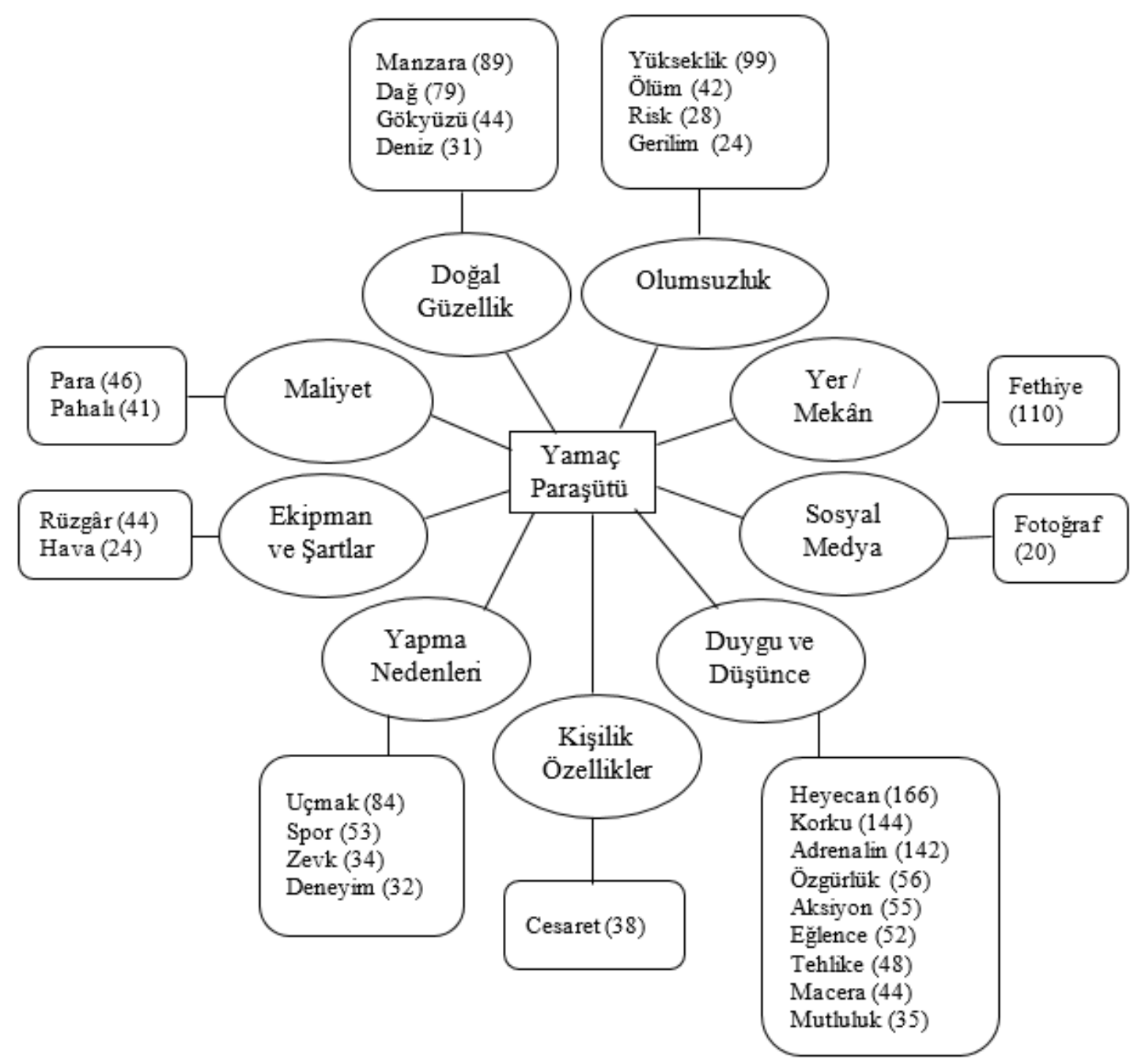

Şekil 1. Kelime İlişkilendirme Testi Sonucunda Oluşturulan Kavram Haritası

Kelime İlişkilendirme Testinin ikinci bölümünde, turizm öğrencilerinin yamaç paraşütü kavramı için kurdukları cümleler incelenmiş ve cümleler içerdikleri anlamlara göre kategorize edilmiştir. Buna göre belirlenen kategoriler ve cümlelerin frekans değerleri Tablo 2'de verilmiştir.

Tablo 2: Anahtar Kavrama İlişkin Kurulan İlgili Cümlelerin Frekans Tablosu

\begin{tabular}{|l|l|l|l|}
\hline $\begin{array}{l}\text { Bilimsel Bilgi İçeren } \\
\text { Cümleler }\end{array}$ & $\begin{array}{l}\text { Bilimsel Olmayan } \\
\text { veya Yüzeysel Bilgi } \\
\text { İçeren Cümleler }\end{array}$ & $\begin{array}{l}\text { Kavram Yanılgısı } \\
\text { İçeren Cümleler }\end{array}$ & Boş \\
\hline $25(\% 10,5)$ & $157(\% 65,7)$ & $44(\% 18,4)$ & $13(\% 5,4)$ \\
\hline
\end{tabular}

Tablo 2 incelendiğinde öğrenciler tarafından kurulan yamaç paraşütü ile ilgili cümlelerin \%65,7'si bilimsel olmayan veya yüzeysel bilgi içeren; \%18,4'ü kavram yanılgısı içeren; \%10,5'i bilimsel bilgi içeren cümleler olduğu ve öğrencilerin \%5,4'ünün cümle kurmadığı görülmektedir. Tablo 2 'de sayıları verilen ilgili cümlelere örnekler aşağıda gösterilmiştir. 
Bilimsel Bilgi İçeren Cümlelere Örnekler:

$>$ Yamaç paraşütü Fethiye'de yapılır.

$>$ Turizm açısından önemli bir spor dalıdır.

> Ülkemizde az yerde yapılan ve oldukça eğitim gerektiren bir macera sporudur.

$>$ Bölge ekonomisine katkı sağlar.

$>$ Bölgeye yeni insanlar çeker ve turizmi canlandırır.

$>$ Dünyaya kendimizi tanıtabilmek için iyi bir yol ve turizm aracıdır.

Bilimsel Olmayan veya Yüzeysel Bilgi İçeren Cümlelere Örnekler:

$>$ Dünyadaki en tehlikeli spor aktivitesidir.

> Yamaç paraşütü keyif ve cesaret içeren bir spordur.

$>$ Özgürlügünü ve korkunu aynı anda yaşamak.

$>$ Çok pahalı bir spordur.

$>$ Yamaç paraşütü, adrenalin sağlar.

> Bu aktiviteyi yapmak eşsiz manzara eşliğinde heyecan dolu zaman geçirmektir.

Kavram Yanılgısı İçeren Cümlelere Örnekler:

> Uçmak güzeldir.

> Yüksek oksijende boğulmak.

$>$ İpler sağlam değil mi?

> Yaşamın rengi özgürlüktedir.

$>$ Aşağı düşersek ölürüz.

$>$ Yamaçtan paraşütsüz atlamayın.

$>$ Ölmek cesaret ister.

$>$ Uçaktan paraşütsüz atlama.

> Yamaç paraşütü hoştur, yolu yokuştur, giden gelmiyor, acep nedendir?

Öğrencilerin yazmış oldukları cümleler incelendiğinde; 25 öğrencinin yamaç paraşütünün nerede yapıldığına, turizm sektörü açısından önemine değindikleri görülmektedir. 157 öğrencinin kurmuş olduğu cümleler ise kısmen bilgi içermekte olup, yamaç paraşütü ile ilgili duygu ve düşüncelere yöneliktir. 44 öğrenci ise kavram yanılgısına düşmüş ve farklı cümleler kurmuşlardır. Yine de cümleler incelendiğinde duygu ve düşünceler ile olumsuzluk konularına değindikleri söylenilebilir.

\section{SONUÇ ve ÖNERILER}

Araştırmada kelime ilişkilendirme testi (KIT) kullanılarak turizm öğrencilerinin yamaç paraşütü kavramına ilişkin bilişsel yapıları belirlenmeye çalışılmıştır. Çalışmaya başlamadan önce öğrencilere daha önce yamaç paraşütü yapıp yapmadıkları sorulmuş ve hiçbirinin yapmadığı tespit edilmiştir. Buna rağmen katılımcıların çoğu, KİT'te yamaç paraşütü kavramına ilişkin istenen on adet cevap için 9-10 kelime yazmıştır. Bu durum katılımcıların verilen kavrama ilişkin yeterli kelime dağarcığına sahip oldukların göstermektedir.

Yapılan çalışmada katılımcılara yamaç paraşütü kavramının ne ifade ettiği sorulmuş ve 239 öğrenciden toplam 132 adet cevap kelime elde edilmiştir. Elde edilen kelimeler doğrultusunda en sik tekrarlanan on kelimenin heyecan $(\mathrm{f}=166)$, korku $(\mathrm{f}=144)$, adrenalin $(\mathrm{f}=142)$, Fethiye $(\mathrm{f}=110)$, yükseklik ( $\mathrm{f}=99)$, manzara ( $\mathrm{f}=89$ ), maliyet $(\mathrm{f}=87)$, uçmak ( $\mathrm{f}=84)$, dağ $(\mathrm{f}=79)$ ve özgürlük ( $\mathrm{f}=56$ ) olduğu belirlenmiştir. Bu da katılımcıların heyecan, korku, adrenalin ve özgürlük duygularıyla 
birlikte muhteşem bir manzaraya karşı uçmak istedikleri, ancak ücretinin yüksek olması sebebiyle yamaç paraşütü yapamadıklarını göstermektedir. Yapılan çalışmalarda da yamaç paraşütü yapmaya iten nedenler arasında heyecan, korku, gökyüzünde olmak, özgürlük hissi yer almaktadır (Paixaol ve Tucher, 2012; Arslan Ayazlar, 2015; Saçlı ve Kahraman, 2019). Bunun yanı sıra çalışmada yamaç paraşütünün yapıldığı yer olarak katılımcıların akıllarına gelen ilk bölge Fethiye'dir. Nitekim Babadağ-Fethiye, Türkiye'nin bilinen uçuş noktaları arasında ilk sırada yer almaktadır (Saçlı ve Kahraman, 2019). Bunun sebebi; Fethiye - Babadağ'dan (1960 m) yamaç paraşütü ile havalandırdığında, gökyüzünde yeşillik ve maviliklerle dolu muhteşem manzarayla iç içe olunması, mavinin tonlarını ve kartpostallardaki Belcekız Sahilini yaklaşık 30-40 dk. izleyerek ve rüzgârın fısıltılarını dinleyerek Ölüdeniz'e iniş yapılması olarak sayılabilmektedir.

Yamaç paraşütü kavramına ilişkin oluşturulan 'Olumsuzluk' kategorisinde dikkat çeken bir diğer kelime ölüm ( $f=42)^{\prime}$ dür. Son yıllarda haberlerde ortaya çıkan paraşüt kazaları ve ölümle sonuçlanmasının bazı öğrencileri etkilediği aşikârdır. Bu da öğrencilerden bazılarının yamaç paraşütü yapılırken ölümle karşı karşıya olduklarını düşündügünü göstermektedir. Benzer şekilde alan yazında da yamaç paraşütünde risk algısının önem teşkil ettiği (Cater, 2006; Paixaol ve Tucher, 2012), yamaç paraşütü kazalarının olduğu (Gauler ve Sauter, 2006) belirtilmiştir.

Yamaç paraşütünü ifade eden ilgili cümlelere bakıldığında turizm öğrencileri tarafından yamaç paraşütünün ne anlama geldiği iyi bir şekilde anlaşıldığı görülmektedir. Çünkü cümle gruplarına bakıldığında bilimsel bilgi içeren ve bilimsel bilgi olmayan veya yüzeysel bilgi içeren cümlelerin daha yoğun olduğu, kavram yanılgısı içeren cümlelerin ise sadece \%18,4'lük bir kesim tarafından kullanıldığı belirlenmiştir. Bu oranlar yamaç paraşütü kavramının turizm eğitimi alan öğrencilerin çoğunluğu tarafından tam olarak algılandığını göstermektedir.

Çalışmada ortaya çıkan sonuçlar doğrultusunda; yamaç paraşütü sporunu gerçekleştiren firmaların ücretleri gözden geçirmesi ve daha fazla kitleye ulaşması önerilebilir. Bunun yanı sıra üniversite dönemi öncesinde ve sonrasında öğrenciler için kampanyalar yapılabilir. Yamaç paraşütü yapmadan önce alınan güvenlik önlemleri dikkatle ve özenle anlatılabilir ve en önemlisi simülasyon ile canlandırma yapılabilir. Tehlikeli bir spor olması sebebiyle bu konu ile ilgili eğitim verilebilir, seminerler düzenlenebilir.

Çalışma sadece Muğla Sıtkı Koçman Üniversitesi Turizm Fakültesi'nde öğrenim gören 3. ve 4. Sınıf öğrencilerine uygulanmıştır. İleride yapılacak çalışmalar da çalışma alanı genişletilerek daha fazla kelimeye ulaşılabilir. Yamaç paraşütü yapan kişilere KİT uygulanabilir. Bunun dışında yamaç paraşütü yapılan bölgelerde turizm sektöründe çalışan kişilere uygulanarak farklı kelimeler ortaya çıkabilir ve bunun sonucu olarak yamaç paraşütü kavramı ile ilgili bölgenin genel yapısı hakkında bilgi sahibi olunabilir. Farklı turizm türleriyle ilgili çalışmalar yapılabilir. Yapılacak çalışmaların sayısı arttıkça kavramın daha iyi anlaşılması ve algılanmasının daha kolay olacağ1 öngörülmekte ve çalışmanın yamaç paraşütüne ilişkin algılara yönelik gelecekteki çalışmalara destek olacağı, yol göstereceği düşünülmektedir. Bunun yanı sıra çoğunlukla eğitim ve fen bilimleri alanlarında kullanılan Kelime İlişkilendirme Testi'nin turizm alanında da kullanılabileceğini gösteren bir çalışma olması sebebiyle, metodolojik katkı sağlayacağı ve alan yazında yenilik oluşturacağı söylenilebilir.

\section{KAYNAKÇA}

Akça, R. (2016). Spor Turizmi. (Editör) Yaylı, A. ve Sürücü, Ö.: Özel İlgi Turizmi içinde (ss. 183204), Ankara: Detay Yayıncilık.

Akoğlan Kozak, M. ve Bahçe, S. (2009). Özel İlgi Turizmi, Ankara: Detay Yayıncılık. 
Akyurt, H. (2019). Turizm Lisans Öğrencilerinin Kelime İlişkilendirme Testi Yöntemi ile Turizm Eğitimi Algılamalarının Ölçülmesi: Giresun Üniversitesi Örneği. Türk Turizm Araştırmaları Dergisi, 3 (3): 759-774.

Akyurt Kurnaz, H. ve Kılıç, B. (2020). Hüzün Turizmi Alt Disiplinler ve Türkiye Destinasyonundan Seçmeler. Ankara: Nobel Yayıncilık.

Ardahan, F. ve Yerlisu Lapa, T. (2011). Açık Alan Rekreasyonu: Bisiklet Kullanıcıları ve Yürüyüşçülerin Doğa Sporu Yapma Nedenleri ve Elde Ettikleri Faydalar. Uluslararası İnsan Bilimleri Dergisi, 8 (1): 1327-1341.

Arslan Ayazlar, R. (2015). Flow Phenomenon as a Tourist Experience in Paragliding: A Qualitative Research. Procedia Economics and Finance, 26: 792-799.

Bahar, M. (2001). Biyoloji Eğitiminde Kavram Haritalarının Kullanımı. Abant İzzet Baysal Üniversitesi Eğitim Fakültesi Dergisi, 1(1): 25-40.

Bahar, M., Johnstone, A. H. and Sutcliffe, R. G. (1999). Investigation of Students' Cognitive Structure in Elementary Genetics Through Word Association Tests, Journal of Biological Education, 33 (3): 134-141,

Bahar, M. ve Özatll, N. S. (2003). Kelime İlişkilendirme Yöntemi ile Lise 1. Sınıf Öğrencilerinin Canlıların Temel Bileşenleri Konusundaki Bilişsel Yapılarının Araştırılması. Balıkesir Üniversitesi Fen Bilimleri Dergisi, 5 (1): 75-85.

Barut, A. İ., Demir, A., Ballıkaya, E. ve Çiftçi, F. (2019). Doğa Yürüyüşü ve Yamaç Paraşütü Sporu Yapan Bireylerin Yaşam Doyumu ve Özyeterliliklerinin İncelenmesi. Spor Eğitim Dergisi, 3 (2): 137-145.

Bucak, T. ve Yiğit, S. (2020). Otel Mutfak Çalışanlarının Mutfak Teknolojilerine Yaklaşımlarının Kelime İlişkilendirme Testi ile Değerlendirilmesi: İzmir Örneği. Journal of Tourism and Gastronomy Studies, 8 (1): 489-500.

Cater, I.C. (2006). Playing with risk? Participant perceptions of risk and management implications in adventure tourism. Tourism Management, 27 (2): 317-325.

Chang, H. and Huang, Y. (2012). Paragliding Adventure Recreation Consumers' Activity Motivation, Enduring Involvement and Their Involved Behavior. The Journal of International Management Studies, 7 (2): 61-74.

Doğan, S., Yücel Güngör M. ve Güngör, O. (2018). Turizm Meslek Yüksekokulu Öğrencilerinin Sosyal Medyaya Yönelik Bilişsel Yapılarının Kelime İlişkilendirme Testi Aracıllğıyla İncelenmesi, Turizm Akademik Dergisi, 5 (1), 166-176.

Ercan, F., Taşdere, A. ve Ercan, N. (2010). Kelime İlişkilendirme Testi Aracılığıyla Bilişsel Yapının ve Kavramsal Değiş̧imin Gözlenmesi. Türk Fen Eğitimi Dergisi, 7 (2): 136-154.

Gauler, R. and Sauter, B. (2006). Paragliding Accidents with Spinal Cord Injury. 10 Years' Experience at a Single Institution. Spine, 31 (10): 1125-1130.

Hsieh, T. C. (2007). Recreational Motivation, Sensation Seeking, and Recreationa linvolvement of Taiwan's Adventure Recreation Participants, Presented to the School of Graduate Studies of the University of the Incarnate Word in Partial Fulfillment of There Quirements for the Degree of Doctor of Philosophy the University of the Incarnate Word.

https://www.tarihlisanat.com/ikarus-yunan-mitolojisi/, Erişim Tarihi: 25.04.2020. 
Karademir, Y. ve Güven, Ö. (2016). Türkiye'de Yamaç Paraşütçülerinin Problemleri. The Journal of Academic Social Science Studies, 48: 433-457.

Keskin, E. ve Örgün, E. (2015). Kelime İlişkilendirme Testi Aracıllı̆ıyla Sürdürülebilir Turizm Olgusunun Kavramsal Analizi: Ürgüp Örneği. Journal of Tourism and Gastronomy Studies, 3(1): 3040.

Keskin, E., Örgün, E. ve Akbulut, B. A. (2017). Gastronomi Kavramının Kelime İlişkilendirme Testi Aracılığıyla Analizi. Journal of Tourism and Gastronomy Studies, 5(3): 255-267.

Kılıç, T. (2015). Nasıl Başardılar? İstanbul: Ares Yayıncılık. https://books.google.com.tr/books?id=_qd6DwAAQBAJ\&printsec=frontcover\&hl=tr\#v= onepage\&q\&f=false, Erişim Tarihi: 25.04.2020.

Koçak, F. ve Balcı, V. (2010). Doğada Yapılan Sportif Etkinliklerde Çevresel Sürdürülebilirlik. Ankara Üniversitesi Çevrebilimleri Dergisi, 2(2): 213-222.

Koday, S., Koday, Z. ve Kızılkan, Y. (2018). Alternatif Turizm Açısından Siirt İlinde Yamaç Paraşütü Faaliyetleri. TÜCAUM 30. Yıl Uluslararası Coğrafya Sempozyumu, 3-6 Ekim 2018, Ankara.

Naidoo, P., Ramseook-Munhurrun, P., Seebaluck, N. V. and Janvier, S. (2015). Investigating the Motivation of Baby Boomers for Adventures Tourism. Procedia - Social and Behavioral Sciences, 175: 244-251.

Nartgün, Z. (2006). Fen ve Teknoloji Öğretiminde Ölçme ve Değerlendirme. (Ed. Mehmet Bahar) Fen ve Teknoloji Öğretimi içinde (s.355-415), Ankara: Pegem Akademi Yayıncllık.

Onat, G. ve Keskin, E. (2019). Organik Gıda Kavramının Kelime İlişkilendirme Testi Aracılı̆̆ıyla Analizi. Journal of Tourism and Gastronomy Studies, 7(4): 3275-3289.

Özçiriş, İ. (2017). Yamaç Paraşütü Pilotlarını Uçuş Öncesi Kaygı ve Stres Düzeyinin Değerlendirilmesi. Yayınlanmamış Yüksek Lisans Tezi. İstanbul Gelişim Üniversitesi Sağlık Bilimleri Enstitüsü, İstanbul.

Paixão1, J. A. and Tucher, G. (2012). Risk Perception for Paragliding Practitioners. International Journal of Sports Science, 2 (2): 6-10.

Pirselimoğlu Batman, Z. ve Demirel, Ö. (2015). Altındere Vadisi Meryemana Deresi Güzergâhında Doğa Temelli Turizm Etkinliği: Yamaç Paraşütü. İnönü Üniversitesi Sanat ve Tasartm Dergisi, 5 (11): 13-26.

Saçlı, Ç. ve Kahraman, C. Ö. (2019). Açık Alan Rekreasyonu Olarak Yamaç Paraşütü Etkinliğine Katılanların Motivasyonları ve Etkinlik Memnuniyetlerinin Belirlenmesi: Arsuzfest Örneği. Dokuz eylül Üniversitesi SBE Dergisi, 21 (4): 1249-1269.

Sarıbaş, O. and Öter, Z. (2013). Risk as a motivation in adventure tourism and its use in terms of tourism marketing. 8th Silk Road International Conference, Development of Tourism in Black and Caspian Seas Regions, 24-26 May 2013, Tbilisi, Georgia.

Swarbrooke, J. and Horner, S. (2007). Consumer Behavior in Tourism. Oxford: Elsevier Butterworth Heinemann.

Taşdere, A., Özsevgeç, T. ve Türkmen, L. (2014). Bilimin Doğasına Yönelik Tamamlayıcı Bir Ölçme Aracı: Kelime İlişsilendirme Testi. Fen Eğitimi ve Araştırmaları Derneği Fen Bilimleri Öğretimi Dergisi, 2 (2): 129-144. 
Timur, B. and Taşar, M. F. (2011). Developing PreService Science Teachers' Cognitive Structures about Technology: Word Association Test (WAT), Western Anatolia Journal of Educational Science, Special Issue, 131-138.

Türk Hava Kurumu (2009). Yamaç Paraşüt Başlangıç Pilot Ĕ̆itim El Kitabı, Ankara: Türk Hava Kurumu Türkkuşu Genel Müdürlüğü Çok Hafif Hava Araçları.

Yücel Güngör, M., Doğan, S. ve Güngör, O. (2017). Aşçıllk Programı Öğrencilerinin Sosyal Medyaya Yönelik Bilişsel Yapılarının Kelime İlişkilendirme Testi Aracılığıyla İncelenmesi, Journal of Tourism and Gastronomy Studies, 2 (18), 206-218. 